\title{
Menjawab Persoalan tentang Imam Besar Abyatar dalam Markus 2:26: Sebuah Kritik Teks
}

\author{
Pujianto Hardjosanjoto \\ Gereja Kristus Ketapang, Jakarta \\ pujiantohs@gmail.com \\ Bakhoh Jatmiko \\ Sekolah Tinggi Theologia Nazarene Indonesia \\ djatcair@gmail.com
}

\begin{abstract}
Mark 2:26 is one of the most disputed texts. The text's pivotal problem is around the accuracy between Jesus' narration and the historical facts in the Old Testament (1 Sam. 21:1-6). This discrepancy implies the authority of Christology and Bibliology in the Christian faith. This research was conducted to examine the text in order to answer the disputes around the text. The authors used a qualitative descriptive research method in this research with a textual criticism approach. The research approaches covered textual history, text's authorship history, and text's grammatical analysis. This research found that there were neither textual errors nor Jesus's mistakes in quoting a history. Addressing Abiathar as high priest is a part of the patristic culture in the priesthood tradition in Israel. Jesus' motive in mentioning Abiathar closely related to the unfaithful story that has made him disposed as a high priest. Thus, the authority of Christ and the Bible as God's Word could not be overthrown by this passage.
\end{abstract}

Keywords: Abiathar; Ahimelech; Mark 2:26;Textual criticism

\begin{abstract}
Abstrak
Markus 2:26 menjadi salah satu teks yang banyak diperdebatkan. Poros persoalan dari teks ini berkisar pada akurasi narasi Yesus dengan fakta sejarah dalam Perjanjian Lama (1Sam. 21:1-6). Ketidaksesuian ini berimplikasi pada otoritas Kristologi dan Bibliologi dalam iman Kristen. Penelitian ini dilakukan untuk mengadakan penggalian teks tersebut untuk menjawab silang pendapat seputar ayat tersebut. Penulis menggunakan metodologi penelitian deskreptif kualitatif dengan pendekatan kritik tekstual. Pendekatan di dalam Analisa yang dilakukan terdiri dari kajian terhadap sejarah naskah, sejarah kepenulisan teks, serta untuk tata bahasa di dalam teks. Penelitian ini menemukan bahwa teks yang dibahas tidak mengandung kesalahan teks, maupun kekeliruan Yesus dalam mengutip kisah sejarah. Penyebutan nama Abyatar sebagai imam besar merupakan bagian dari budaya patristik dalam tradisi keimaman di Israel. Motif penggunaan nama Abyatar oleh Yesus sangat terkait dengan riwayat ketidaksetiaannya, yang membuatnya ditolak sebagai imam besar. Dengan demikian, otoritas Kristus dan Alkitab sebagai Firman Allah tidak dapat dibantah dengan menggunakan ayat ini.
\end{abstract}

Kata Kunci: Abyatar; Ahimelek; Markus 2:26; Kritik Teks 


\section{PENDAHULUAN}

Salah satu isu yang banyak diperdebatkan mengenai Injil Markus berkaitan dengan siapa penulisnya. Namun, keyakinan tradisional serta pendekatan sastra maupun jurnalistik mengaitkan Injil ini dengan figur Markus atau Yohanes Markus sebagai keyakinan yang kredibel. ${ }^{1}$ Di dalam Injil-Nya, penulis meriwayatkan pelayanan dan pengajaran Yesus di dalam tulisannya. Berkaitan dengan pengajaran tentang Sabat, Markus mencatat bahwa Yesus mengutip salah satu kisah dari Daud yang memakan roti kudus dari Rumah Allah.

Di dalam Markus 2:26, NestleAland melaporkan bahwa Yesus berkata,

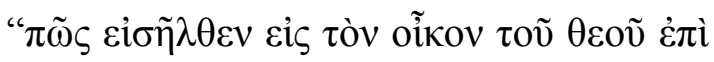

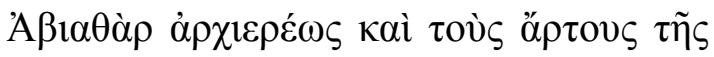

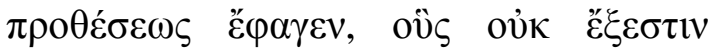

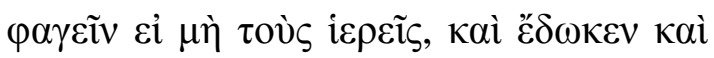

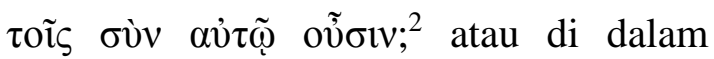
bahasa Indonesianya adalah, "bagaimana ia masuk ke dalam Rumah Allah waktu Abyatar menjabat sebagai Imam Besar lalu makan roti sajian itu - yang tidak boleh dimakan kecuali oleh imam-imamdan memberinya juga kepada pengikut-

${ }^{1} \mathrm{~S}$ Swastoko, "Kredibilitas Penulis Injil Markus Dalam Kajian Jurnalistik," Jurnal Teologi Gracia Deo 2, no. 1 (2019): 36-45.

2 Barbara Aland, Aland Kurt, and Matthew Black, The Greek New Testament, 4th ed. (Federal Republic of Germany: United Bible Societies, 1993), 95. pengikutnya?" (Markus 2:26). ${ }^{3}$ Teks ini menjadi masalah ketika bagian Perjanjian Lama yang menjadi rujukan penulis Markus mengacu pada 1 Samuel 21:1-6.

Pokok yang menjadikan teks ini sangat terkenal adalah frasa "waktu Abyatar menjabat sebagai Imam Besar" atau dalam bahasa Inggrisnya "when Abiathar was high priest."4 Hal ini menjadi bahan diskusi karena peristiwa itu diyakini terjadi bukan di masa Abyatar menjabat sebagai Imam, melaikan ayah Abyatar, Ahimelekh yang menjabat sebagai Imam Besar. Teks ini merupakan salah satu narasi di dalam Injil yang memang memerlukan pendekatan khusus untuk memahaminya. ${ }^{5}$

Abyatar, anaknya, yang pada akhirnya menjadi Imam Besar pada masa Daud dan Salomo menjadi raja Israel (1Sam. 8:17, 2Sam. 20:25, 1Raj. 2:27, 1Raj. 4:4, 1Taw18:16), muncul pertama kali di dalam narasi 1Sam. 22:20 sebagai anak Ahimelekh yang lolos dari pembantaian yang dilakukan oleh Saul atas penduduk di Nob.

${ }^{3}$ Semua kutipan Alkitab, kecuali diberi catatan, diambil dari ALKITAB Terjemahan Baru LAI, 1974.

${ }^{4}$ Biblical Studies Press, The NET Bible First Edition, 2nd ed. (Biblical Studies Press, 2006), 26.

5 David Rhoads, "Narrative Criticism and the Gospel of Mark," Journal of the American Academy of Religion 50, no. 3 (1982): 411-434. 
Jika frasa "waktu Abyatar menjabat sebagai Imam Besar" dianggap merupakan suatu kesalahan, maka implikasi yang ditimbulkan dari frasa ini cukup besar, yaitu runtuhnya doktrin Kewibawaan Alkitab. Bart D. Ehrman berpendapat bahwa adanya ketidaksesuaian semacam ini dalam Alkitab menunjukkan bahwa teks Alkitab memiliki persoalan yang perlu diselesaikan. ${ }^{6}$ Bukan hanya itu saja, ketidaksesuaian ini akan berimplikasi pada rapuhnya apologetika Kristen dan celah bagi serangan yang ditujukan pada doktrin Kekristenan. ${ }^{7}$

Implikasi lain yang ditimbulkan dari frasa "waktu Abyatar menjabat sebagai Imam Besar" adalah masalah yang berhubungan dengan doktrin Kristologi ortodoks yang dipegang oleh gereja-gereja injili pada umumnya. Lebih jauh, jika Yesus ternyata melakukan kesalahan, kewibawaan doktrin Kristologi akan runtuh dan membawa efek domino pada pokok ajaran gereja yang lain. ${ }^{8}$

6 Bart D. Ehrman, Misquoting Jesus: Kesalahan Penyalinan Dalam Perjanjian Baru Kisah di Balik Siapa Yang Mengubah Alkitab dan Apa Alasannya (Jakarta: Gramedia Pustaka Utama, 2006), 248.

7 Leith Gray and Andrea Gray, "A Muslim Encounters the Gospel of Mark: Theological Implications of Contextual Mismatch," International Journal of Frontier Missions 25, no. 3 (2008): 127-134.

8 "Mark 2:26 and the Problem of Abiathar | Bible.Org," accessed December 23,
Oleh karena itu beberapa pertanyaan penelitian di dalam kajian ini adalah: Apakah frasa "waktu Abyatar menjabat sebagai Imam Besar" benar merupakan suatu kesalahan? Jika memang frasa itu dianggap salah, maka siapa yang salah? Apakah para penyalin pada masa awal menyalin secara salah injil Markus, yang kemudian mempengaruhi para saksi yang lain dan menjadi teks yang utama? Jika hal tersebut benar maka manakah varian pembacaan yang paling mendekati teks asli? Atau mungkinkah sumber penulisan Markus salah? Tetapi bilamana yang terjadi sebaliknya. Jika sumber ${ }^{9}$ yang menjadi rujukan penulisan Markus benar, mungkinkah Yesus melakukan kesalahan ketika ia mengutip bagian dari Perjanjian Lama.

\section{METODE PENELITIAN}

Metode penelitian yang digunakan adalah deskreptif kualitatif. Penulis melakukan penyelidikan dengan menggunakan kaidah penelitian historis kritis khususnya kritik tekstual ${ }^{10}$ yang

2020

${ }^{9}$ Para Bapa Gereja umumnya sependapat bahwa Petrus lah nara sumber utama penulisan injil Markus.

10 Beberapa kelompok juga menyebut analisa ini dengan pendekatan analisaTeks (Textual Analysis) yang di dalam bidang kesusatraan merupakan pemikiran - bukan usaha 
meliputi kajian terhadap naskah atau teks-teks cetakan, salinan-salinan kuno, dan sumber-sumber pemberita lain yang resmi, yang dianggap bisa membantu memahami teks Alkitab; kajian terhadap unsur-unsur sejarah dan budaya kepenulisan teks; serta kajian terhadap unsur teks dan gramatikalnya. ${ }^{11}$ Kajian ini merupakan cabang dari filologi yang dikembangkan di Eropa pada abad 19 dan $20 .{ }^{12}$

Untuk memperkaya khazanah pembahasan, penulis juga melakukan kajian literatur yang berkaitan dengan teks yang dibahas. Studi literatur dilakukan untuk melihat dan mengkaji pandangan para Ahli. Penulis akan berusaha menginventarisir berbagai pendapat dan pandangan yang berkaitan dengan diskusi terhadap Markus 2: 26.

\section{HASIL DAN PEMBAHASAN}

Sebelum penulis pendekatan eksegetikal terhadap frasa "waktu

mencari kesalahan, tetapi dengan adil dan benar menilai kebaikan serta kejelekan sesuatu secara terus terang dan obyektif. Josh McDowell, Apologetika: Volume 2 (Malang: Penerbit Gandum Mas, 2003), hal. 95.

11 Ernst Boogert, "Review of: Fundamentals of New Testament Textual Criticism, by Stanley E. Porter and Andrew W. Pitts, A Journal of Biblical Textual Criticism 21," Review \& Expositor 115, no. 1 (2018): 128-130.

12 By Michael Witzel, "Textual Criticism in Indology and in European Philology during the 19th and 20th Centuries," Electronic Journal of Vedic Studies 21, no. 3 (2014): 9-91.
Abyatar menjabat sebagai Imam Besar", ada baiknya kita melihat apa pandangan para ahli tentang frasa ini.

\section{Survei Pandangan Para Ahli}

Pandangan para ahli penulis dapatkan melalui studi literatur. Selain melakukan pendekatan onomastikal, ${ }^{13}$ para ahli juga melakukan pendekatan historis kristis pada teks. Dari kajian yang dilakukan, penulis membaginya kedalam dua kelompok. Kelompok pertama adalah pandangan yang didasarkan atas Teks Asli dan Penyalinan, sedangkan kelompok kedua adalah pandangan yang didasarkan atas Penerjemahan dan Pemahaman terhadap teks tersebut.

Pandangan yang Didasarkan Teks Asli dan Penyalinan

$$
\text { Kaiser }^{14} \text {, Guelich }{ }^{15} \text { dan Metzger }{ }^{16}
$$
pada umumnya menyanggah pendapat

13 Lihat Bakhoh Jatmiko, "Kajian Onomastika Teks Perjanjian Baru Mengenai Transmisi Nama Diri Di Dalam Alkitab," PASCA: Jurnal Teologi dan Pendidikan Agama Kristen 16, no. 1 (2020): 40-49.

14 Pandangan yang Didasarkan Teks Asli dan Penyalinan Walter C. Kaiser, Hard Sayings of the Bible (InterVarsity Press, 2010), 411.

${ }^{15}$ Pandangan yang Didasarkan Teks Asli dan Penyalinan Robert A. Guelich, Word Biblical Commentary: Mark 1-8:26, Word Biblical Commentary, 34A ed. (Dallas: Word, Incorporated, 2002), 121.

16 Bruce Manning Metzger and United Bible Societies, A Textual Commentary on the Greek New Testament, Second Edition a Companion Volume to the United Bible Societies' Greek New Testament, 4th ed. (London; New York: United Bible Societies, 1994), 68. 
yang menyatakan adanya kesalahan pada teks yang terdekat dengan teks aslinya.Mereka berpendapat bahwa teks yang terdekat dengan teks aslinya memang menyatakan bahwa Abyatar pada waktu itu menjabat sebagai Imam Besar ketika ditemui oleh Daud.

Joel Marcus menyatakan bahwa rujukan pada nama Abyatar merupakan suatu kesalahan, dimana nama Abyatar dan Ahimelekh ayahnya tertukar pada waktu teks tersebut disalin. ${ }^{17}$ Brook agak sedikit berbeda dengan Joel Marcus. Ia, pada pendapatnya yang pertama menyatakan bahwa Markus mengalami kesalahan ingatan (memory slip) dimana ia semestinya menuliskan kata Imam saja tetapi ia malah menuliskan kata Imam Besar. ${ }^{18}$ Brooks juga punya pendapat lain tentang masalah ini. Ia berargumen bahwa nama Ahimelekh pada naskah ini ditulis sebagai Abba-Abyatar (yang artinya "ayah dari Abyatar," yaitu Ahimelekh) tetapi dikemudian hari secara tidak sengaja kata Abba dihilangkan oleh para penyalin naskah ketika mereka menyalin naskah kitab Markus. Secara khusus ketika para penyalin menyalin

17 Joel Marcus, Mark 1-8: A New Translation with Introduction and Commentary, Anchor Bible (New York: Double Day, 2000), 241-242.

18 James A. Brooks, Mark, Electronic Ed., Logos Library System; The New American Commentary, 23rd ed. (Nashville: Broadman \& Holman, 2001), 66. kata-kata yang berasal dari bahasa Aram.

Beda halnya dengan Laneyang berpendapat akan adanya "primitive error" (kesalahan tradisi) di dalam kasus ini. ${ }^{19}$ Kesalahan ini menjadi bagian dari tradisi yang diwarisi oleh Markus ketika ia menuliskan injilnya. Selain itu Lane berpendapat bahwa bisa juga terjadi karena para penyalin Alkitab di masa awal memasukkan komentar ini menjadi bagian dari teks. ${ }^{20}$ Hal yang hampir senada dinyatakan oleh Blomberg.Ia berpendapat bahwa kesalahan tersebut terjadi ketika para penyalin salah mengerti tentang apa yang ditulis Markus di Markus 2:26 pada saat teks tersebut disalin. $^{21}$

Pandangan yang Didasarkan Penerjemahan dan Pemahaman

Kesulitan teks ini berusaha dikaji oleh beberapa penafsir. Misalnya, Blomberg berpendapat bahwa tata bahasa yang digunakan Markus pada Mrk. 2:26 "in [the passage about] Abiathar [the] high priest- [dalam cerita tentang] Imam Besar Abyatar" sebentuk dengan tata bahasa yang digunakan pada Mrk. 12:26

19 William Lane, The Gospel According To Mark: The English Texts With Introduction, Exposition and Notes (Grand Rapid: Eerdmans, 1993), 115-116.

20 Lane, The Gospel According To Mark: The English Texts With Introduction, Exposition and Notes.

21 Craig L. Blomberg, The Historical Reliability of the Gospel (Downers Grove: InterVarsity, 1987), 193. 
("in [the passage about] the bush dalam cerita tentang semak duri"), dimana susunan kalimat tersebut dapat dimengerti sebagai referensi yang merujuk bagian dari Kitab Suci dimana kejadian tersebut berlangsung. ${ }^{22}$

Wallace berbeda pandangan dengan Blomberg. Ia melakukan kajian hermeneutik terhadap Mrk. 2:26 dalam bahasa aslinya, bahasa Yunani. Ia melakukan kajian tata bahasa pada kata

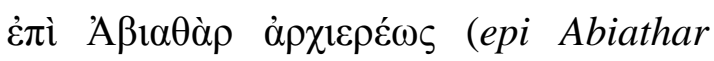
arkhiereōs) khususnya penggunaan kata غ̇ंगे.

Wallace menyatakan bahwa bentuk epi + kata benda genitif di luar Markus yang digunakan pada frasa epi Abiathar arkhiereōs (waktu Abyatar menjabat sebagai Imam Besar" atau dalam bahasa Inggrisnya "when Abyatar was high priest" ) sering kali digunakan untuk menyatakan suatu masa yang artinya sama dengan "pada masa ....."23 Amdt dan lainnya memiliki pendapat serupa bahwa epi + kata benda genitif, yang berhubungan dengan waktu, akan mempunyai arti "in the time of - pada jamannya, under - dimasa (raja atau the Gospel.

${ }^{22}$ Blomberg, The Historical Reliability of

23 Daniel Wallace, "MMark and the Problem of Abiathar' (Makalah Dipresentasikan Pada Evangelical Theological Society, Southwest Regional Meeting," Dallas Theological Seminary, 17. penguasa). ${ }^{24}$ Sebagai contoh adalah Lukas 4:27 dan Lukas 3:2. Lebih lanjut Wallace menyatakan bahwa penggunaan $\dot{\varepsilon} \pi \grave{~}+$ kata benda genitif pada Lukas 3:2 itu sebangun dengan Mark 2:26. Hal ini membuktikan bahwa teks Lukas 3:2 dengan jelas mendukung kerangka waktu umum dari frasa "in the time of - pada jamannya Imam Besar Abyatar". Atas dasar ini Ia berpendapat bahwa Yesus tidak salah kutip bagian Perjanjian Lama.

Pendapat Wallace didukung oleh Brooks yang mengusulkan agar frasa "in the days of Abyatar the high priestwaktu Abyatar menjabat Imam Besar", dimengerti sebagai "in the account of" (dalam kisah). ${ }^{25}$ Pengertian tersebut akan menyelaraskan narasi Markus 2:26 dengan narasi dari Kitab Samuel yang berhubungan dengan Abyatar.

Sayangnya Gundry tidak sependapat dengan mereka. Ia berpendapat bahwa Yesus memang "salah kutip" bagian dari PL. ${ }^{26}$

${ }^{24}$ A Greek-English Lexicon of the New Testament and Other Early Christian Literature William Arndt, Frederick W. Danker, and Walter Bauer, "Based on Walter Bauer's GriechischDeutsches Wrterbuch Zu Den Schriften Des Neuen Testaments Und Der Frhchristlichen," 200AD, 363.

25 Brooks, Mark, Electronic Ed., Logos Library System; The New American Commentary.

26 Robert H. Gundry and Mark, A Commentary on His Apology for the Cross (Grand Rapids, Mich: Eerdmans, 1993), 141. 
Tabel 1. Ringkasan Pendapat Para Ahli Tentang Frasa "epi Abiathar arkhiereōs"

\begin{tabular}{|c|c|c|c|}
\hline No. & Nama Ahli & Terjemahan Ahli & $\begin{array}{c}\text { Terjemahan Bahasa } \\
\text { Indonesia }\end{array}$ \\
\hline 1 & Craig L. Blomberg & $\begin{array}{l}\text { in [the passage about] } \\
\text { Abiathar [the] high priest }\end{array}$ & $\begin{array}{l}\text { [dalam cerita tentang] } \\
\text { Abyatar, sang Imam Besar itu }\end{array}$ \\
\hline 2 & James A. Brooks & $\begin{array}{l}\text { In the days of Abiathar the } \\
\text { high priest } \\
\text { Abba-Abiathar the high } \\
\text { priest }\end{array}$ & $\begin{array}{l}\text { waktu Abyatar menjabat } \\
\text { Imam Besar } \\
\text { Ayah Abyatar, sang Imam } \\
\text { Besar itu }\end{array}$ \\
\hline 3 & William L. Lane & $\begin{array}{l}\text { When Abiathar was high } \\
\text { priest (primitive error) }\end{array}$ & $\begin{array}{l}\text { waktu Abyatar menjabat } \\
\text { sebagai Imam Besar }\end{array}$ \\
\hline 4 & Bruce M. Metzger & 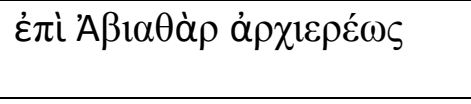 & $\begin{array}{l}\text { waktu Abyatar menjabat } \\
\text { sebagai Imam Besar }\end{array}$ \\
\hline 5 & Robert H. Gundry & $\begin{array}{l}\text { in the time of Abiathar the } \\
\text { high priest (NASB) }\end{array}$ & $\begin{array}{l}\text { pada masa hidup Abyatar, } \\
\text { sang Imam Besar itu }\end{array}$ \\
\hline 6 & Walter C. Kaiser & 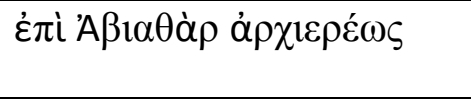 & $\begin{array}{l}\text { waktu Abyatar menjabat } \\
\text { sebagai Imam Besar }\end{array}$ \\
\hline 7 & Joel Marcus & $\begin{array}{l}\text { in the time of Abiathar the } \\
\text { high priest }\end{array}$ & $\begin{array}{l}\text { pada masa hidup Abyatar } \\
\text { sang Imam Besar itu }\end{array}$ \\
\hline 8 & Robert A. Guelich & $\begin{array}{l}\text { in the entitled about } \\
\text { Abiathar the high priest }\end{array}$ & $\begin{array}{l}\text { dalam kisah tentang Abyatar, } \\
\text { sang Imam Besar itu }\end{array}$ \\
\hline 9 & Daniel B. Wallace & $\begin{array}{l}\text { the time of Abiathar was } \\
\text { high priest }\end{array}$ & $\begin{array}{l}\text { pada masa hidup Abyatar, } \\
\text { sang Imam Besar itu }\end{array}$ \\
\hline
\end{tabular}

Eksegesis Markus 2:26

Dalam bab sebelumnya kita sudah melihat pandangan para ahli terkemuka mengenai frasa "waktu Abyatar menjabat sebagai Imam Besar" (Mrk. 2:26). Pada bagian ini penulis akan menggali pemahaman yang lebih mendalam untuk dapat menjawab permasalahan seputar phrasa tersebut.

\section{Kajian Tekstual Markus 2:26}

Kajian ini digunakan untuk menentukan mana teks yang mendekati aslinya (autograph). Untuk melakukan hal ini, Penulis melakukan kajian pustaka atas manuskrip-manuskrip yang ada. Proses Kajian Tekstual tersebut dapat dilihat pada Lembar Kerja di bawah ini. 


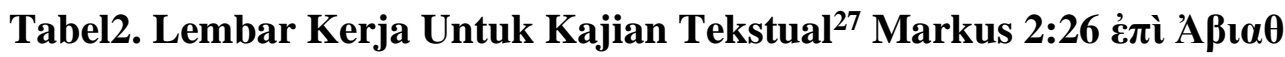
à $\rho \dot{\alpha} \rho \chi \varepsilon \rho \varepsilon ́ \omega \varsigma^{28}$

\begin{tabular}{|c|c|c|}
\hline \multicolumn{3}{|c|}{ Macam Pembacaan } \\
\hline 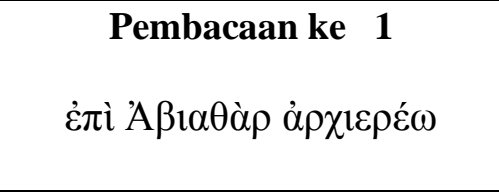 & 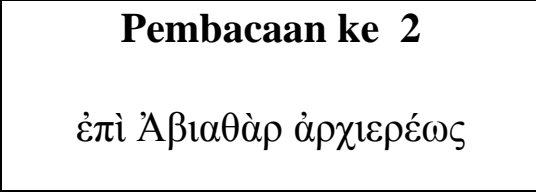 & $\begin{array}{c}\text { Pembacaan ke } 3 \\
\text { Menghilangkan frasa } \dot{\varepsilon} \pi \grave{1} \\
\text { A } \beta 1 \alpha \theta \dot{\alpha} \rho \dot{\alpha} \rho \chi 1 \varepsilon \rho \varepsilon ́ \omega \varsigma\end{array}$ \\
\hline $\begin{array}{l}\text { Artinya: } \\
\text { ia masuk ke dalam Rumah } \\
\text { Allah pada waktu Abyatar } \\
\text { sebagai Imam Besar } \\
\text { "he entered into the house } \\
\text { of God in [the time of] } \\
\text { Abiathar [the] high priest, } \\
\text { and ate" }\end{array}$ & $\begin{array}{l}\text { Artinya: } \\
\text { ia masuk ke dalam Rumah } \\
\text { Allah pada masa hidup Imam } \\
\text { Besar Abyatar } \\
\text { "he entered into the house of } \\
\text { God in [the time of] Abiathar } \\
\text { the high priest, and ate" }\end{array}$ & $\begin{array}{l}\text { Artinya: } \\
\text { ia masuk ke dalam Rumah } \\
\text { Allah dan makan } \\
\text { "he entered into the house } \\
\text { of God, and ate" }\end{array}$ \\
\hline $\begin{array}{l}\text { Bukti eksternal : } \\
\text { S = Codex Sinaiticus } \\
\text { (uncial dari abad ke empat; } \\
\text { naskah Alexandria; kategori } \\
\text { I) } \\
\text { B = Codex Vaticanus } \\
\text { (uncial dari abad ke empat; } \\
\text { naskah Alexandria; kategori } \\
\text { I) } \\
\text { K = Paris } \\
\text { (disalin pada abad ke-9; } \\
\text { naskah Byzantine) } \\
\text { L= Roma } \\
\text { (disalin pada abad ke-8; } \\
\text { naskah Alexandria) } \\
8921010=\text { minuskul } \\
\text { Byz Lect = Byzantine } \\
\text { lectionary } \\
\text { lat vg = latin vulgata } \\
\text { (akhir abad ke empat hingga } \\
\text { abad ke lima; naskah Barat) } \\
\text { syr(p,h) =syria philoxeniana } \\
\text { (disalin dari abad ke 7) }\end{array}$ & $\begin{array}{l}\text { Bukti Eksternal : } \\
\text { A = Codex Alexandrinus } \\
\text { (uncial dari abad ke lima; } \\
\text { naskah Alexandria ; kategori } \\
\text { III) } \\
\text { C = Codex Epharemi } \\
\text { (uncial dari abad ke-5; naskah } \\
\text { Alexandria; kategori II) } \\
\text { Theta = Koridethi } \\
\text { (disalin pada abad ke-9; } \\
\text { naskah Kaisarea) } \\
\text { Pi = Leningrad } \\
\text { (disalin pada abad ke-9; } \\
\text { naskah Byzantine) } \\
\text { 074= uncial (disalin pada } \\
\text { abad ke 6) } \\
\text { f1 = Lake family (disalin pada } \\
\text { abad ke 12-14; naskah } \\
\text { Kaisarea) } \\
\text { f13 28 33 565 700 1241 = } \\
\text { Ferrar family (disalin pada } \\
\text { abad ke 11-13; naskah } \\
\text { Kaisarea) }\end{array}$ & $\begin{array}{l}\text { Bukti Eksternal : } \\
\text { D = Codex Bezae } \\
\text { (uncial dari abad ke-6; } \\
\text { naskah Barat; kategori IV) } \\
\text { W = Washingston } \\
\text { (Disalin dari abad ke-5) } \\
10091546^{*}=\text { minuskul } \\
\text { (disalin dari abad ke } 8) \\
\text { lat = latin } \\
\text { syr(s) = syria sinaiticus } \\
\text { (disalin dari abad ke-4) } \\
\text { syr(pal) = syria } \\
\text { palestina (disalin dari abad } \\
\text { ke-5) }\end{array}$ \\
\hline
\end{tabular}

${ }^{27}$ A Student's Guide to Textual Criticism of the Bible Paul D. Wegner, Its History, Methods \& Results (Downers Grove, Ill: InterVarsity Press, 2006), 228.

${ }^{28}$ Nestle Eberhard, Nestle Erwin, and Aland Kurt, Novum Testamentum Graece, At Head of Title: Nestle-Aland., 27th ed. (Stuttgart: Deutsche Bibelstiftung, 1993), 95. 
$\operatorname{syr}(\mathrm{pal})=$ syria palestina (disalin dari abad ke 5)

\section{Bukti Eksternal:}

Pembacaan pertama, di dukung oleh bukti-bukti eksternal yang cukup kuat dimana teks paling awal dari pembacaan tersebut berasal dari naskah penyalinan abad keempat, dengan kualitas penyalinan yang paling akurat, yaitu dari Codex Sinaiticus dan Vaticanus. Penyebaran juga cukup baik (Sinaiticus dan Vaticanus).

Pembacaan kedua, di dukung oleh bukti-bukti eksternal yang kurang kuat dimana teks paling awal dari pembacaan tersebut berasal dari naskah penyalinan abad ke lima, dengan kualitas penyalinan yang kurang akurat, yaitu dari codex Alexandria, naskah Kaisarea (abad ke 9) dan Byzantine (abad ke 9). Pembacaan kedua merupakan pembacaan yang paling tersebar cakupan geografinya.

Pembacaan ke tiga, didukung oleh bukti eksternal yang lemah karena didasarkan atas Codex bezae, dimana kualitas penyalinan dari naskah ini terkenal paling buruk. Usia teks paling muda. Penyebaran juga kurang karena hanya didukung oleh teks Barat.

\section{Kesimpulan:}

Pembacaan pertama dan kedua cukup berimbang dalam hal bukti-bukti eksternal, untuk itu harus diuji melalui pengujian atas bukti-bukti internal untuk membuktikan pembacaan mana yang mendekati autograf.

\section{Bukti Internal:}

Pembacaan yang pertama dianggap sebagai pembacaan yang paling akurat bila didasarkan atas bukti internal yang ada, yaitu pembacaan yang paling pendek, pembacaan yang paling sulit dan pembacaan yang paling kurang selaras dengan ayat-ayat paralelnya.

Pembacaan kedua gagal atas bukti internal pembacaan yang paling pendek, pembacaan yang paling sulit dan pembacaan yang paling kurang selaras dengan ayat-ayat paralelnya karena adanya penambahan $\underline{\tau o \tilde{v}}$. Penambahan ini membuktikan adanya kecenderung para penyalin melakukan penyelarasan dengan injil sinoptik (Mat. 12:4, Luk. 6:4) guna menghindari masalah dengan narasi yang ada di 1Sam. 21:1-6, dimana Ahimelekhlah yang menemui Daud, bukan Abyatar.

\section{Kesimpulan: ${ }^{29}$}

Penulis mengambil kesimpulan bahwa pembacaan pertama merupakan pembacaan yang paling mendekati teks asli karena didukung oleh bukti eksternal yaitu berasal dari teks yang paling awal dengan kualitas yang paling baik dan memenuhi tiga dari empat kriteria bukti internal.

${ }^{29}$ Bruce Terry, "Memberikan Penilaian A Sebagai Hasil Atas Kajiannya Tekstualnya Terhadap Teks Markus 2:26." 
Berdasarkan tabel di atas dapat dibuktikan bahwa bacaan pertama adalah bacaan yang mendekati aslinya (autograph). Jadi teks itulah yang harus digunakan sebagai dasar untuk melakukan eksegese berikutnya, yaitu Kajian Sejarah dan Budaya serta Kajian Tata Bahasa.

Kajian Sejarah dan Budaya Markus 2:26

Frasa "waktu Abyatar menjabat sebagai Imam Besar" yang diucapkan oleh Yesus mempunyai dimensi yang sangat luas. Dimensi itu berkenaan dengan istilah "Imam Besar". Istilah yang disematkan pada Abyatar. Istilah ini harus dilihat dari dimensi sejarah dan budaya yang ada pada masa itu, yaitu masa Perjanjian Baru. ${ }^{30}$

Pada masa perjanjian Baru, Herodes berhasil merebut hak bagi dirinya untuk mengangkat seorang Imam Besar. Kemampuan Herodes untuk mengangkat sesorang menjadi Imam Besar telah semakin menghancurkan tradisi jabatan Imam Besar dipegang seumur hidup. ${ }^{31}$ Setelah Herodes meninggal, maka penunjukkan Imam

\footnotetext{
${ }^{30}$ Joanna Dewey, "The Literary Structure of the Controversy," Journal of Biblical Literature 92, no. 3 (2016): 394-401.

31 "Priest, High" W. O. McCready, The International Standard Bible Encyclopedia, Revised, Ed. (Grand Rapids: Eerdmans, 1988), 962-963.
}

Besar menjadi tanggung jawab kekaisaran Roma.

Imam Besar pertama yang disebutkan di dalam Perjanjian Baru adalah Hanas seorang Saduki (6-15 Masehi). Hanas digantikan oleh kelima puteranya dan oleh Kayafas putera menantunya (18-36 Masehi). ${ }^{32}$ Secara politis Imam besar adalah pemimpin Sanhedrin dan juga mewakili bangsa Yahudi untuk berhadapan dengan para pejabat kekaisaran Roma. ${ }^{33}$ Jabatan Imam Besar berakhir seiiring dengan hancurnya Bait Allah.

Selain itu penelitian menunjukkan penyebutan Imam Besar ini dapat juga merujuk pada mantan Imam Besar dan anggota keluarga dari Imam Besar, contohnya Mat. 2:4; 16:21; 20:18; 21:15; Luk. 3:2. ${ }^{34}$ Pendapat ini didukung oleh Gordon $^{35}$, Keener ${ }^{36}$ dan Vine ${ }^{37}$. Mereka

32 “Annas” Paul J. Achtemeier, Harper's Bible Dictionary, Includes Index., 1st ed. (San Francisco: Harper \& Row, 1985), 31.

${ }^{33}$ McCready, The International Standard Bible Encyclopedia, Revised, Ed.

34 "Priest" W. E. Vine et al., Vine's Complete Expository Dictionary of Old and New Testament Words, 2nd ed. (Nashville: T. Nelson, 1996), 486-487.

35 Robert P Gordon, I \& II Samuel: A Commentary (Waynesboro, GA: Paternoster Press, 2004), 169-170.

36 Craig S. Keener and InterVarsity Press, The IVP Bible Background Commentary: New Testament, 2nd ed. (Downers Grove, Ill: InterVarsity Press, 1993), 26.

37 "ARCHIEREUS" W.E. Vine and F.F. Bruce, Vine's Expository Dictionary of Old and New Testament Words, ed. Revell, 2nd ed. (Old Tappan NJ: electronic form by Logos Research Systems, 1996), 486. 
menyatakan bahwa penyebutan kata "Imam Besar" di dalam Perjanjian Lama berlaku bagi mereka yang termasuk di dalam keluarga Imam Besar (1 Samuel 1:9). ${ }^{38}$ Hal ini juga didukung oleh Evans dengan mengusulkan pendekatan penafsiran pada budaya patristic dalam kesejarahan teks. ${ }^{39}$

Maka berdasarkan Kajian Sejarah dan Budaya dapat dikatakan bahwa Markus tidak melakukan suatu kesalahan ketika Ia menyebut Abyatar sebagai Imam Besar sewaktu menulis Injilnya. Markus menyebut Abyatar sebagai Imam Besar karena ia mengacu pada kebiasaan yang ada pada masa itu, dimana sebutan Imam Besar dapat diterapkan kepada mantan Imam Besar dan anggota keluarga dari Imam Besar yang masih menjabat (Luk. 3:2; Yoh. 18:13; Kis. 4:6). Atas dasar itu dapat disimpulkan bahwa tidak ada yang salah dengan penggunaan Frasa "waktu Abyatar menjabat sebagai Imam Besar", baik dari sisi Markus si penulis maupun sumber utama penulisannya, yaitu Yesus.

Argumentasi di atas menjawab persoalan tentang ketidaksesuaian di dalam teks dengan pendekatan budaya.

38 Vine and Bruce, Vine's Expository Dictionary of Old and New Testament Words.

39 Craig A. Evans, "Patristic Interpretation of Mark 2:26 'When Abiathar Was High Priest," Vigiliae Christianae 40 (1986): 183-186.
Namun, pertanyaan lanjutan tentang munculnya nama Abyatar di dalam teks adalah mengapa tokoh ini yang diangkat Yesus di dalam narasinya, dan bukan Ahimelekh? Tentu saja semua ini ada karena sebuah tujuan. Yesus tidak sembarangan mengutip, demikian pula Markus tidak sembarangan menarasikan kisah.

Tokoh Abyatar nampaknya merupakan "kartu truf" untuk menyelesaikan persoalan yang terkait dengan keluhan orang Farisi terhadap murid-murid-Nya yang dinilai melanggar tradisi Sabat. Perrin berargumentasi bahwa Yesus memilih menyebut nama Abyatar karena kaitanya dengan pengalaman ketidaksetiaannya dalam memegang jabatan keimaman. ${ }^{40} 1$ Rajaraja 1:7 mencatat tentang pemberontakan Abyatar dengan beroposisi melawan dinasti Daud. Hal ini membuat tradisi jabatan keimaman yang seharusnya ada pada dirinya dialihkan kepada orang lain (1Raj. 1:8; 2:26-27).

Lebih jauh, Perrin menjelaskan bahwa Markus 2:23-28 harus dilihat dalam konteks yang lebih luas berkaitan dengan pertentangan antara Yesus beserta murid-murid-Nya dengan Imam besar

40 Nicholas Perrin, From Creation to New Creation: Biblical Theology and Exegesis, ed. D M Gurtner and B L Gladd (Hendrickson Publishers, 2013), 175. 
dan para pengikutnya. ${ }^{41}$ Yesus melihat "kebengkokan" dan ketidaksetiaan para imam yang melayani di Bait Allah pada waktu itu. Kemurnian hukum Allah telah ditinggalkan dan digantikan dengan tradisi-tradisi legalistik yang jauh dari nilai kesalehan sejati. Nama Abyatar menjadi pukulan telak untuk para imam dan ahli hukum seperti orang farisi. Yesus menyinggung ketidaklurusan pemahaman mereka tentang hukum dengan menggunakan figur Abyatar yang tidak setia dan akhirnya dibuang dari jabatan keimamannya.

Kajian Tata Bahasa Markus 2:26

Frasa epi Abiathar arkhiereos bila diterjemahkan secara berdiri sendiri akan berarti sebagaimana LAI menyatakannya di Alkitab kita yaitu "waktu Abyatar menjabat sebagai Imam Besar". Pada frasa ini ada tiga kata yang akan penulis kaji yaitu kata epi, kata Abiathar, dan yang terakhir adalah kata arkhiereōs. ${ }^{42}$

Kata غ̇лì (epi) pada frasa ini berbentuk preposition genitive (kata depan genitif). Arndt dan lainnya dalam A Greek-English Lexicon of the New Testament and Other Early Christian Literature (BDAG), menyatakan bahwa

\footnotetext{
41 Ibid.

42 Penulis mengunakan bantuan Bibleworks 7.0 untuk melakukan Kajian Tatab

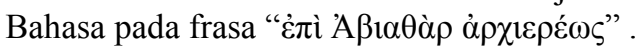

salah satu penggunaan kata غ̇ंì (epi) berkenaan dengan waktu, yaitu "in the time of (pada waktu). ${ }^{, 43}$

Penulis memilih "in the time of (pada waktu)" sebagai arti dari kata غ̇ं ì ketika digunakan sebagai kata depan genitif pada frasa "Ẻ $\pi \grave{~} A \beta 1 \alpha \theta \grave{\alpha} \rho$

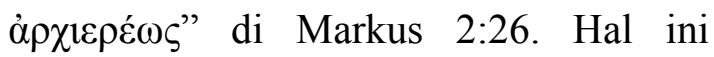
didasarkan atas kesamaan bentuk penggunaan kata غ̇ंì yaitu غ̇ंì bentuk preposition genitive (kata depan genitif). Bentuk ini digunakan di Matius 1:11 (pada waktu pembuangan ke Babel), Lukas 3:2 (pada waktu Hanas dan Kayafas menjadi Imam Besar), Kisah Para Rasul 11: 28 (pada zaman Klaudius) dan juga Lukas 4:27 (pada zaman nabi Elisa). ${ }^{44}$

Wallace menyatakan bahwa berdasarkan kaidah tata bahasa غ̇ंì dapat berbentuk sebagai kata depan datif, genitif dan akusatif, dimana masingmasing penggunaannya dapat mempunyai arti yang berhubungan dengan "spatial (ruang/tempat)", "temporal (waktu)" dan “cause (penyebab)." ${ }^{45}$ Secara lebih lanjut

43 "Based on Walter Bauer's GriechischDeutsches Wrterbuch $\mathrm{Zu}$ Den Schriften Des Neuen Testaments Und Der Frhchristlichen [Sic] Literatur, Sixth Edition, Ed. Kurt Aland and William Arndt, Frederick W. Danker, and Walter Bauer, "A Greek-English Lexicon of the New Testament and Other Early Christian Literature," n.d.

44 Ibid.

45 Daniel B. Wallace, Greek Grammar Beyond the Basics - Exegetical Syntax of the New Testament (Zondervan: House and Galaxie Software, 1999), 742. 
Wallace menyatakan bahwa bila غ̇ंì digunakan sebagai kata depan genitif yang berkenaan dengan waktu, maka غ̇ंì akan mempunyai dua arti, yaitu "in the time of (pada waktu)" dan "during (selama atau pada waktu). ${ }^{46}$

'A $\beta 1 \alpha \theta \grave{\alpha} \rho$ - Abiathar 'Abyatar', kata ini menunjuk pada diri Abyatar, imam di Nob (1Sam. 21:1; 22:10). Ia merupakan anak dari Ahimelekh, imam di Nob. Abyatarlah yang dikemudian hari menggantikan posisi ayahnya. Abyatar jauh lebih terkenal dibanding ayahnya karena ia melayani dua raja dari kerajaan Israel bersatu, yaitu pada masa Daud dan Salomo sebagai Imam Besar. Di masa Salomo ia bersama-sama dengan Zadok bertugas sebagai Imam Besar.

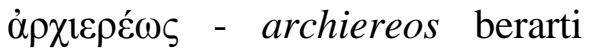
Imam Besar, imam yang tertinggi menurut jabatan Imam di dalam Perjanjian Baru dan hanya ada di dalam Perjanjian Baru. ${ }^{47}$ Di Perjanjian Lama, istilah archiereos hanya muncul 5 kali dalam kitab-kitab kanon dari LXX, tetapi disebut sebanyak 41 kali di kitab Apokrifa. LXX menterjemahkan MT hakkohen haggadôl, sebagai imam besar, kohen haro's, atau imam kepala secara harafiah, atau diterjemahkan secara bebas

\footnotetext{
46 Wallace, Greek Grammar Beyond the Basics - Exegetical Syntax of the New Testament.

47 Vine and Bruce, Vine's Expository Dictionary of Old and New Testament Words.
}

sebagai imam. ${ }^{48}$

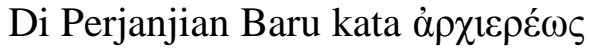
hanya muncul di Injil (Mat. 25 kali, Mrk. 22 kali, Luk. 15 kali, Yoh. 22 kali), Kis. (22 kali) dan Ibrani (17 kali). Kata ini di Injil dan Kisah Para Rasul merujuk pada para imam besar yang menentang Yesus. Di Ibrani kata ini secara signifikan menunjuk pada karya penyelamatan dan ke allahan Yesus, dimana kata ini menunjukkan bahwa Yesus merupakan Imam Besar yang sejati. Kata Imam Besar di Injil dan Kisah Para Rasul, selalu menunjuk pada orang yang memimpin Sanhedrin (Mat. 26:62; Mrk, 14:60; Kis. $5: 21 ; 27 ; 23: 1)$, tetapi kata ini sering juga merujuk pada para tua-tua atau elders dan para ahli taurat atau scribes, (Mat. 16:21; Mrk. 8.31; Luk. $9: 22) .{ }^{49}$

Frasa epi Abiathar arkhiereōs bila diterjemahkan akan mempunyai dua arti. Arti yang pertama adalah ketika kata غ̇лì dari frasa tersebut diterjemahkan sebagai “during (selama atau pada waktu), maka arti dari frasa ini adalah "waktu Abyatar menjabat sebagai Imam Besar", tetapi bila epi diterjemahkan sebagai "in the time of (pada waktu)" maka arti dari

48 "Priest,High Priest" J. Baehr and Colin Brown, New International Dictionary of New Testament Theology (Grand Rapids: Zondervan Mich, 1992), 35.

49 Baehr and Brown, New International Dictionary of New Testament Theology. 
Abiathar arkhiereōs adalah "pada jamannya Imam Besar Abyatar." Arti kedua jauh lebih mungkin digunakan. Hal ini terlihat dari adanya kesamaan bentuk pada bagian-bagian lain dari Alkitab yang juga menggunakan epi sebagai kata depan genitif. Penggunaan bentuk ini menghasilkan arti yang sama juga yaitu "in the time of (pada waktu)". 50

Jadi, berdasarkan kesamaan penggunaan bentuk غ̇ $\pi \grave{i}$ sebagai kata depan genitif pada bagian-bagian lain dari Alkitab maka penulis memutuskan untuk memilih arti yang kedua karena waktu yang ada pada arti yang kedua menjadi lebih luas, sehingga peristiwa yang dirujuk oleh Yesus di Markus 2:26 itu menjadi sinkron dengan 1Sam. 21:1, dimana peristiwa itu dapat terjadi di masa hidup Abyatar, yang dikemudian hari diteguhkan menjabat sebagai Imam besar. Hal ini selaras dengan pendapat Bruce Terry dari Ohio Valley University dimana ia menyatakan bahwa Idiom Bahasa Yunani dari epi Abiathar arkhiereōs secara umum mempunyai arti "during the time that Abiathar was high priest." ${ }^{51}$

Jadi dapat disimpulkan bahwa secara gramatika tidak ada yang salah

${ }^{50}$ Arndt, Danker, and Bauer, "A GreekEnglish Lexicon of the New Testament and Other Early Christian Literature." Jam 17:41,., dengan apa yang Markus tulis, karena apa yang Markus tulis sebenarnya mencerminkan pengetahuannya akan budaya yang berlaku pada saat itu dan juga selaras dengan bagian-bagian lain dari kitab-kitab yang terdapat di Perjanjian Baru (Matius 1:11; Lukas 3:2; Kisah Para Rasul 11: 28 dan juga Lukas $4: 27)$.

\section{KESIMPULAN}

Berdasarkan hasil kajian yang dilakukan terhadap Markus 2:26 dengan pendekatan kritik teks yang meliputi Kajian Sejarah dan Budaya dan Kajian Tata Bahasa membuktikan bahwa frasa "waktu Abyatar menjabat sebagai Imam Besar" tidak mengandung kesalahan. Frasa ini tidak mengandung kesalahan baik dari sisi teks, atau dari sisi Yesus sebagai sumber utama penulisan Markus maupun dari sisi Markus, si penulis Injil Markus. Penyebutan nama Abyatar di dalam teks berkaitan dengan riwayat kehidupannya yang ditulis di dalam Kitab Suci sebagai figur imam yang tidak setia. Yesus menunjuk hidung para imam Bait Allah yang legalistik dan lebih mengutamakan tradisi dengan mengangkat contoh Abyatar yang dibuang Allah dari hadapan-Nya.

Kajian atas frasa "waktu Abyatar menjabat sebagai Imam Besar" 
membuktikan diperlukannya berbagai pendekatan dalam melakukan kajian atas teks-teks bermasalah yang ada pada Alkitab. Penafsir tidak dapat menjustifikasi kewibawaan Alkitab atau hal-hal lain yang berkenaan dengan doktrin hanya atas dasar satu kajian. Hal ini disebabkan tiap-tiap kajian mempunyai kekuatan dan kelemahannya. Kejelian penafsir dalam menentukan metode penafsiran akan menentukan hasil tafsiran yang dapat dipertanggung jawabkan.

\section{DAFTAR PUSTAKA}

Achtemeier, Paul J. Harper's Bible Dictionary, Includes Index. 1st ed. San Francisco: Harper \& Row, 1985.

Arndt, William, Frederick W. Danker, and Walter Bauer. "A Greek-English Lexicon of the New Testament and Other Early Christian Literature," n.d.

' "Based on Walter Bauer's Griechisch-Deutsches Wrterbuch Zu Den Schriften Des Neuen Testaments Und Der Frhchristlichen," 200AD.

Baehr, J., and Colin Brown. New International Dictionary of New Testament Theology. Grand Rapids: Zondervan Mich, 1992.

Barbara Aland, Aland Kurt, and Matthew Black. The Greek New Testament. 4th ed. Federal Republic of Germany: United Bible Societies, 1993.

Blomberg, Craig L. The Historical Reliability of the Gospel. Downers
Grove: InterVarsity, 1987.

Boogert, Ernst. "Review of:

Fundamentals of New Testament

Textual Criticism, by Stanley E.

Porter and Andrew W. Pitts, A

Journal of Biblical Textual Criticism

21." Review \& Expositor 115, no. 1

(2018): 128-130.

Brooks, James A. Mark, Electronic Ed., Logos Library System; The New American Commentary. 23rd ed. Nashville: Broadman \& Holman, 2001.

Dewey, Joanna. "The Literary Structure of the Controversy." Journal of Biblical Literature 92, no. 3 (2016): 394-401.

Eberhard, Nestle, Nestle Erwin, and Aland Kurt. Novum Testamentum Graece, At Head of Title: NestleAland. 27th ed. Stuttgart: Deutsche Bibelstiftung, 1993.

Ehrman, Bart D. Misquoting Jesus : Kesalahan Penyalinan Dalam Perjanjian Baru - Kisah Di Balik Siapa Yang Mengubah Alkitab Dan Apa Alasannya. Jakarta: Gramedia Pustaka Utama, 2006.

Evans, Craig A. "Patristic Interpretation of Mark 2:26 'When Abiathar Was High Priest."' Vigiliae Christianae 40 (1986): 183-186.

Gordon, Robert P. I \& II Samuel : A Commentary. Waynesboro, GA: Paternoster Press, 2004.

Gray, Leith, and Andrea Gray. "A Muslim Encounters the Gospel of Mark: Theological Implications of Contextual Mismatch." International Journal of Frontier Missions 25, no. 3 (2008): 127-134.

Guelich, Robert A. Word Biblical Commentary: Mark 1-8:26, Word Biblical Commentary. 34A ed. Dallas: Word, Incorporated, 2002. 
Gundry, Robert H., and Mark. A Commentary on His Apology for the Cross. Grand Rapids, Mich: Eerdmans, 1993.

Jatmiko, Bakhoh. "Kajian Onomastika Teks Perjanjian Baru Mengenai Transmisi Nama Diri Di Dalam Alkitab." PASCA: Jurnal Teologi dan Pendidikan Agama Kristen 16, no. 1 (2020): 40-49.

Kaiser, Walter C. Hard Sayings of the Bible. InterVarsity Press, 2010.

Keener, Craig S., and InterVarsity Press. The IVP Bible Background Commentary : New Testament. 2nd ed. Downers Grove, Ill: InterVarsity Press, 1993.

Lane, William. The Gospel According To Mark: The English Texts With Introduction, Exposition and Notes. Grand Rapid: Eerdmans, 1993.

Marcus, Joel. Mark 1-8: A New Translation with Introduction and Commentary, Anchor Bible. New York: Double Day, 2000.

McCready, W. O. The International Standard Bible Encyclopedia, Revised, Ed. Grand Rapids: Eerdmans, 1988.

Nicholas Perrin. From Creation to New Creation: Biblical Theology and Exegesis. Edited by D M Gurtner and B L Gladd. Hendrickson Publishers, 2013. https://books.google.co.id/books?id= p6AHmwEACAAJ.

Press, Biblical Studies. The NET Bible First Edition. 2nd ed. Biblical Studies Press, 2006.

Rhoads, David. "Narrative Criticism and the Gospel of Mark." Journal of the American Academy of Religion 50, no. 3 (1982): 411-434.

Societies, Bruce Manning Metzger and United Bible. A Textual
Commentary on the Greek New

Testament, Second Edition a

Companion Volume to the United

Bible Societies' Greek New

Testament. 4th ed. London; New

York: United Bible Societies, 1994.

Swastoko, S. "Kredibilitas Penulis Injil Markus Dalam Kajian Jurnalistik."

Jurnal Teologi Gracia Deo 2, no. 1 (2019): 36-45.

http://www.sttbaptisjkt.ac.id/ejournal/index.php/graciadeo/article/v iew/30.

Terry, Bruce. “, Diakses Pada Tanggal , Jam 17:41,."

. "Memberikan Penilaian A

Sebagai Hasil Atas Kajiannya

Tekstualnya Terhadap Teks Markus 2:26."

Vine, W. E., F. Merrill, White William, and Unger. Vine's Complete Expository Dictionary of Old and New Testament Words. 2nd ed. Nashville: T. Nelson, 1996.

Vine, W.E., and F.F. Bruce. Vine's Expository Dictionary of Old and New Testament Words. Edited by Revell. 2nd ed. Old Tappan NJ: electronic form by Logos Research Systems, 1996.

Wallace, Daniel. "'Mark and the Problem of Abiathar' (Makalah Dipresentasikan Pada Evangelical Theological Society, Southwest Regional Meeting." Dallas Theological Seminary.

Wallace, Daniel B. Greek Grammar Beyond the Basics - Exegetical Syntax of the New Testament. Zondervan: House and Galaxie Software, 1999.

Wegner, Paul D. Its History, Methods \& Results. Downers Grove, Ill: InterVarsity Press, 2006.

Witzel, By Michael. “Textual Criticism 
in Indology and in European

Philology during the 19th and 20th

Centuries." Electronic Journal of

Vedic Studies 21, no. 3 (2014): 9-

91.

"Mark 2:26 and the Problem of Abiathar

Bible.Org." Accessed December 23,

2020. https://bible.org/article/mark-

226-and-problem-

abiathar\#_ftnref39. 
84 | SANCTUM DOMINE: Jurnal Teologi, vol. x, no. 1 (2020) 